\title{
Relationship Analysis of Eco-Control, Company Age, Company Size, Carbon Emission Disclosure, and Economic Consequences
}

\author{
AMBARWATI \\ Universitas Pamulang Tangerang Selatan \\ DODY HAPSORO* \\ STIE YKPN Yogyakarta \\ CRESCENTIANO AGUNG WICAKSONO \\ AA YKPN Yogyakarta
}

\begin{abstract}
The purpose of this study is to examine the effect of eco-control, company age, and company size on the disclosure of carbon emissions and examine the effect of disclosure of carbon emissions on economic consequences. Specifically, this study uses gas, oil, and coal companies in countries included in Non-Annex I members. Partial Least Square is used as an analysis technique using the WarpPLS 4.0 software. From the test results, it can be shown that eco-control, company age, and company size positively influence the carbon emission disclosure. Furthermore, disclosure of carbon emissions positively influences the trading volume and negatively affects bid-ask spreads and stock price volatility. This research has implications for companies and governments. Stakeholders will respond positively to companies that care about the environment. The government can disclose carbon emissions, a mandatory disclosure for companies that have the potential to produce carbon emissions.
\end{abstract}

Keywords: Economic Consequences, Eco-Control, Carbon Emission Disclosure

\begin{abstract}
Abstrak: Penelitian ini bertujuan untuk menguji pengaruh eco-control, umur perusahaan dan ukuran perusahaan terhadap pengungkapan emisi karbon dan menguji pengaruh pengungkapan emisi karbon terhadap konsekuensi ekonomi. Secara khusus, penelitian ini menggunakan perusahaan minyak, gas, dan batubara di negara-negara yang termasuk dalam anggota Non-Annex I. Partial Least Square digunakan sebagai teknik analisis dengan menggunakan aplikasi WarpPLS4.0. Berdasarkan hasil pengujian, dapat ditunjukkan bahwa eco-control, umur perusahaan dan ukuran perusahaan secara positif berpengaruh terhadap pengungkapan emisi karbon. Selanjutnya, pengungkapan emisi karbon secara positif berpengaruh terhadap volume perdagangan dan secara negatif berpengaruh terhadap bid-ask spread dan volatilitas harga saham. Penelitian ini berimplikasi terhadap perusahaan dan pemerintah. Pemangku kepentingan akan merespon secara positif perusahaan yang peduli terhadap lingkungan. Pemerintah dapat menjadikan pengungkapan emisi karbon sebagai pengungkapan wajib untuk semakin meningkatkan kepedulian perusahaan terhadap lingkungan.
\end{abstract}

Kata Kunci: Konsekuensi Ekonomi, Eco-control, Pengungkapan Emisi Karbon

* Corresponding author: dodyhapsoro@gmail.com 


\section{Introduction}

Climate change is one of the effects of global warming that occurs at present. This was triggered due to an increasing concentration of greenhouse gases in the earth's atmosphere. According to Sullivan and Gouldson (2013), industrial activity is a major contributor to greenhouse gases in the earth's atmosphere. The company is expected to contribute to reducing global warming caused by greenhouse gases from the company's industrial activities.

In addition, the internal audit function can be described as part of the solution to overcome weaknesses in the internal control system, the reporting of business activities, and the ethical behavior of businesspeople (IIA, 2015). Asiedu \& Deffor (2017) stated that an effective internal audit function could reduce and prevent corruption and administrative errors. Because of the increasing importance of internal audits in ensuring corporate governance's efficiency, legislation as a formal corporate governance guideline has reinforced the importance of the professional level and ethical responsibilities of internal audits in public and private organizations. Therefore, the study of the factors that motivate internal auditors to fulfill these responsibilities becomes very important (Sekerka, 2011; Khelil et al., 2016; Khelil et al., 2018).

Several studies have revealed that fear of retaliation is the main cause of the silence of internal auditors who do not report the fraud and corruption they find (Cassematis \& Wortley, 2013; James, 2003; Khelil et al. et al. 2016). Retaliation often takes place in physical and psychological forms such as job loss, intimidation, death threats, defamation, and negative impacts on the internal auditor's career, all of which can reduce the auditors' moral courage to act as whistle-blowers (Comer \& Schwartz, 2017; Keil et al. 2010; Miceli et al. 1991). Sekerka et al. (2009) indicated that moral courage is an attribute that motivates and enables individuals to take appropriate actions based on the ethics of their profession. Morales-Sánchez \& Cabello-Medina (2013) further support this opinion and report that prosocial behavior, such as speaking, requires moral courage. This moral courage is a moral competence that can overcome the fear of doing the right thing following a belief in moral values. 
Global warming, declining biodiversity, and ozone depletion are ecological degradation caused by significant industrial developments, although this also provides several benefits, such as ecological efficiency and image enhancement (Porter and Linde, 1995; Shrivastava, 1995). This condition also encourages accounting science to contribute to environmental issues by integrating them into financial statements. One form of its product is environmental management accounting (EMA). EMA is the result of integrating environmental management and management accounting (Bennett et al., 2002).

The central concept of EMA is to help companies exploit potential opportunities and be environmentally responsible due to their operational activities (Schaltegger and Burritt, 2000). Management policies to integrate environmental problems in each of the company's strategic policies are called eco-control (Henri et al., 2017). Financial methods and strategies that focus on environmental control are intended to improve environmental management. In recent years, eco-control has attracted the attention of many parties, especially researchers and companies, to manage corporate environmental strategies that benefit them financially and ecologically (Henri and Journeault, 2010).

The United Nations responded to climate change by establishing a forum called the United Nations Framework Convention on Climate Change (UNFCC). The result of the convention was an international agreement known as the Kyoto Protocol. The Kyoto Protocol is the procedure for reducing greenhouse gas emissions (Kyoto Protocol, 1998). Greenhouse gas emissions regulated in the Kyoto Protocol are carbon dioxide (CO2), methane ( $\mathrm{CH} 4)$, nitrous oxide (N2O), sulfur hexafluoride (SF6), perfluorocarbons (PFC), and hydrofluorocarbons (HFC).

The Kyoto Protocol regulates Annex I member countries (developed countries) to reduce greenhouse gas emissions, while for non Annex I member countries (undeveloped countries) are not required to reduce emissions. The United Nations Framework Convention on Climate Change (UNFCCC) explains that the Kyoto Protocol sets a period for achieving emission reduction targets. This period is known as 
the first commitment. The first commitment of Annex I member countries that are required to reduce greenhouse gas emissions began in 2008 until 2012. In the first period, 39 developed industrial countries that are Annex I members committed to reducing emissions. While at the same time, developing countries are not required to reduce their emissions (Bebbington and Gonzalez, 2008). According to the UNFCCC, reducing carbon emissions continued in the second period, known as the second commitment. The second commitment starts from 2013 to 2020.

The Kyoto Protocol mechanism in implementing emission reduction utilizes the Joint Implementation Mechanism, Emission Trading, and Clean Development Mechanism. According to Irwanthoko and Basuki (2016), the Kyoto Protocol can be a means of implementing carbon accounting. Carbon accounting is the obligation of the business firm to recognize, measure, record, present, and disclose carbon emissions.

Companies that implement eco-control will greatly assist in controlling measuring and disclosing environmental performance. Technically, eco-control will provide integrated information to make the right decision to ensure environmental objectives can be achieved (Henri and Journeault, 2010), eco-control policies integrating information system components (Ittner et al., 2003).

Some environmental accounting articles argue that disclosure of emissionspollution and the performance of corporate pollution reduction are closely related to firm size. Costs and expenses needed to reduce pollution and manage environmental impacts are more easily paid by larger companies (Freedman and Jaggi, 2005). Thus, a company that has long been established and known to the public is expected can meet the expectations and needs of stakeholders.

Disclosure of corporate social responsibility and disclosure of carbon emissions in the annual report are types of voluntary environmental disclosure (Andrew and Cortese, 2011). The company refers to the carbon disclosure project (CDP) to disclose climate change (Najah, 2012). According to signal theory, the company is committed to disclosing more information in disclosure to reduce the possibility of information asymmetry (Hapsoro, 2006). Carbon emission disclosure is a disclosure related to the 
company's responsibility for environmental pollution related to carbon emissions. A good company image to stakeholders related to the firm's concern for the environment is expected to be created by this disclosure.

In several countries, including in Indonesia, there are already many researchers who research deals with the disclosure of carbon emissions. For example, in Indonesia, a study was conducted by Irwanthoko and Basuki in 2016 with the title "Carbon Emission Disclosure: Study on Indonesian Manufacturing Companies". In other countries is a study conducted by Choi et al. (2013) with the title "An Analysis of Australian Company Carbon Emission Disclosures". This research generally puts the carbon emission disclosures variable as an independent variable or dependent variable. So far, no studies have been conducted that place the carbon emission disclosure variable as a connecting variable (moderation or mediation) amongst the independent variable (eco-control) and the dependent variable (economic consequences).

This research was conducted for two reasons. The first reason is that matters relating to environmental issues and climate change also lead to developments in accounting, namely the emergence of an idea called environmental management accounting (EMA). The concept of EMA helps management make decisions about using resources more efficiently and helps management achieve corporate goals without ignoring its environmental responsibilities (IFAC 1998). As part of EMA, eco-control is an application that can assist management in controlling and overcoming various problems related to environmental impacts caused by the company's activities. The second reason is based on Leuz and Verrecchia's (2000) research, which showed that the more disclosures by the company would have more economic consequences. Accordingly, the researcher is interested in examining the effect of eco-control, company age, and company size on the disclosure of carbon emissions. It then examines the effect of carbon emission disclosure on the economic consequences of gas, oil, and coal companies in Non-Annex I member countries. 


\section{Theoretical Framework and Hypothesis Development}

\subsection{Theoretical Framework}

The theory review section contains explanations and descriptions of theories that have relevance relevant to research. Theories that focus on socio-political perspectives, such as legitimacy theory and stakeholder theory and information asymmetry, can explain GHG information's voluntary disclosure (Choi et al., 2013; Tauringana and Chithambo, 2014).

\subsubsection{Agency Theory}

The cooperative relationship between the actor (company owner) and the agent (company management) is explained in the agency theory. The principal delegates the management of the company to the agent so that the company can run well. On the one hand, the agency, as the management of the company has more information than the owner. The main issue is that the agent will make a decision that benefits himself compared to the owner with the information they have.

The right theory to explain voluntary disclosure is agency theory. Company managers who, because of their position, have access to more information, can be evidence of information asymmetry as explained by agency theory. Thus, to reduce agency costs, managers need to have good communication skills to share information with stakeholders (Barako et al., 2006). Stakeholders can use information about GHG emissions to understand the company's values, policies, and motives for addressing environmental impacts. (Ahmad and Hossain, 2015). Management can choose the information relevant to the company, but management tends to hide bad news about the company.

\subsubsection{Signaling Theory}

Explanations regarding information originating from management can be conveyed to users of financial reports or annual reports explain in detail by signal theory (Jama'an, 2008). Investors can catch information signals published by the company 
(financial and non-financial information) to decide (Hartono, 2014). Signal theory explains that managers can predict the company's future performance by having more information than outsiders. Managers can improve company performance and image by disclosing relevant information in annual reports and financial statements (Healy and Palepu, 2001).

Disclosure of company environmental information in annual reports and financial statements can be a means of conveying signals to stakeholders that the company has concern for the environment (Gray et al., 1995). Investors will be interested in this activity, which can further increase the company's value and enhance their positive reputation. Signals that indicate the quality of company management can be represented by disclosing the company's environment as a corporate social responsibility activity. Signals for financial market participants and other stakeholders can be represented by the quality of financial statements, which shows that management can control the environment and corporate social risk.

Sometimes the information related to GHGs or other disclosures contained in annual report do not reflect the company's real efforts to tackle global warming but only wants to build a good reputation and outlook from the perspective of investors (Tang and Luo, 2014). This situation is often referred to as the phenomenon of "greenwashing". Therefore, the public needs accountable and accurate information to assess its sustainability, one of which is through the company's annual report.

Companies that have good performance normatively will voluntarily disclose various matters related to carbon emissions as a signal to stakeholders compared to companies with poor performance. Thus, the information presented by the company in the annual report is true, so that information can be used by interested parties to make decisions, especially to assess the company's commitment to climate change, and assess the risks caused by carbon exposure as a result of the company's operational activities (Tang and Luo, 2014). 


\subsubsection{Legitimacy Theory}

According to Guthrie et al. (2004), rulers and norms that apply to the communities where the company operates become a benchmark for the company in carrying out operational activities and need to ascertain that operational activities are still within the limits of existing rules. The company will obtain legitimacy and guarantee long-term operational sustainability if the company can meet the community's demands so that both parties between the company and the community benefit.

According to Najah (2012), social pressure from the community and stakeholders to fulfill voluntary social contracts encourages companies to make comprehensive disclosure. Therefore, companies are bound by social contracts that require action following the wishes of society. The organization's motivation for environmental disclosure can be explained comprehensively with the legitimacy theory (Pellegrino and Lodhia, 2012). Communication of corporate social activities through disclosure can increase legitimacy (Berthelot and Robert, 2011).

The information held by the company can be a proof of the company's concern for the values that exist in society or as evidence that the company can manage the negative impacts resulting from the company's operational activities (Gray, 2010). Disclosure implies that openness is a basis of public trust towards the management of the corporation system (Hapsoro, 2006). Companies can obtain stakeholder legitimacy for their operational activities thru disclosures in annual reports and financial statements to ensure the sustainability of company operations (Hermawan et al., 2016).

\subsubsection{Stakeholder Theory}

The manager is considered to have an implicit relationship with shareholders and other stakeholders such as creditors, governments, analysts, the public, nature, and the environment. Therefore, stakeholders have the same rights as shareholders in obtaining information about the company (Tauringana and Chithambo, 2014). According to Guthrie et al. (2004), the stakeholder theory explains that the company management is expected to conduct the activities mandated by the stakeholders and report them. The 
stakeholder owns the rights to receive information regarding the impact that will result from the activities conducted by the company. Therefore, the company should give the stakeholders attention due to their position as the parties that directly or indirectly are affected by the company's activities.

Information related to the performance of carbon emissions, the company's effort to reduce carbon emissions, as well as the firm's contribution in managing environmental impacts that are reflected in the disclosure of carbon emissions and the other disclosures shall provide benefits for stakeholders to make decisions (Rahmana et al., 2014). According to Lash and Wellington (2007), the company is expected by stakeholders to be able to assess and report the resulting emissions because carbon reporting and management by the company will be utilized to manage and assess business risks and opportunities related to climate change.

The motivation of companies in reporting continuous activities, including contributions to climate change, can be comprehensively explained in the stakeholder interest theory and the theory of legitimacy through managerial perspectives. The reason used is business-focused, pointing to the fact that maintaining good stakeholder relationships and a positive impression of the company within society are important outcomes of sustainability reporting from a managerial perspective (Comyns and Figge, 2015).

\subsubsection{Eco-Control}

There are some key issues in conventional management accounting that can hamper the search for better EMA systems. Some of these main problems, namely the neglect of environmental costs, the merging of general costs with environmental costs, and accounting for externalities, and social problems. In other words, spending only focuses on operational issues, while problems related to the social environment tend to be ignored (Nuwan and Lee, 2015).

Initially, as a part of EMA, eco-control is introduced to help the company control, measure, and express their environmental performance. Eco-control can be defined as 
"the formalized procedures and systems that use financial and ecological information to maintain or alter patterns in environmental activity". The concept indicates that financial and environmental performance information should be an integral aspect of formal procedures and systems within organizations (Henri and Journeault, 2010; Nuwan and Lee, 2015).

Eco-control, as an application of a management control system, is used to encourage desirable actions and changed unwanted behavior (Merchant, 1982). Variations in processing, production, and material costs are some of the outcomes of eco-control, which positively impact the company's economic performance. Expense variation can also contribute to improving the image and developing the company's competitive advantage.

\subsubsection{Company Age}

Lawer and Andreas (2013) stated that the company's age is calculated since its establishment. The company's age shows that the company can sustainably continue operational activities and compete with other companies. The company's age is closely related and influences financial statements because it corresponds to the company's growth and development. Long-standing companies are estimated to provide comprehensive information on carbon emissions and concrete efforts made by companies to reduce them.

Older companies have a greater percentage of gaining a good reputation in social responsibility involvement and greater legitimacy than younger companies (Juhmani, 2014. Logically, the information provided to stakeholders will be more and more complete if the firm has been operating for a long time. This affects the public image and broad social networks.

\subsubsection{Company Size}

According to Machfoedz (1994), company size is a scale that can be classified by the company's size in various ways, including total sales, total assets, market 
capitalization, and others. The company's size is only divided into three categories: small companies, medium companies, and large companies. The categorization is classified by using the total assets owned by the company.

The company's resources could be reflected in its size (Irwanthoko and Basuki, 2016). Also, the company's size can reflect the number of operational activities carried out by the company. In general, large companies that have greater and more resources will have more operational activities as well (Choi et al., 2013).

\subsubsection{Carbon Emission Disclosure}

According to Choi et al. (2013), the company entity needs to know and communicate the contribution to global warming of the carbon emissions produced. The Kyoto Protocol has implications for companies to conduct assessments, documentation, and presentations, and disclose carbon emissions. The implication is to make the company responsible for operational activities and to encourage the company to make a tangible manifestation in reducing carbon emissions (Irwanthoko and Basuki, 2016).

As the effects of global warming, companies are asked to communicate their role in reducing carbon emissions that cause global warming (Choi et al., 2013). According to Irwanthoko and Basuki (2016), the Kyoto Protocol creates carbon accounting for companies. Carbon accounting requires firms to recognize, measure, record, present, and communicate carbon emissions.

According to Najah (2012), carbon emission disclosure is information about the carbon emissions level resulting from the company's industrial activities and corporate financial management in managing the impacts of climate change. Carbon emission disclosure in this study uses a disclosure index developed by Choi et al. (2013). This disclosure is designed based on the construction of the elements identified in the information request sheet developed by the CDP. CDP (Carbon Disclosure Project) is an independent non-profit organization that provides information on global climate change. The CDP divides the disclosure into five categories: risks and opportunities of 
climate change ( $\mathrm{CC} /$ Climate Change), greenhouse gas (GHG) emissions, energy consumption (EC/Energy Consumption), greenhouse gas reduction and costs (RC/ Reduction and Cost) and accountability for carbon emissions (AEC/Accountability of Emission Carbon). Within these five categories, 18 items were identified. The purpose of the Carbon Disclosure Project is to ensure investors are well informed about the risks and opportunities faced by companies due to climate change (Zhang et al., 2012).

\subsubsection{Economic Consequences}

According to Zeff (1978), in his article titled "The Rise of Economic Consequences", the economic consequences are defined as "the impact of accounting reports on the behavior of business decision-makers, creditors, investors, and governments". Meanwhile, according to Leuz and Wysocki (2016), the economic consequences are defined as the impact of changes in the disclosure regulation on financial statements. Non-financial information, which is the disclosure of financial, environmental performance impacts contained in annual reports, will have economic consequences (Gozali et al., 2002). The level of transparency of the company's management must be able to represent the existence of economic benefits that will be received by the stakeholders, especially investors. Economic consequences are that the accounting report can affect real decisions by managers and others despite reports and changes in the accounting report, not affecting cash flow (Hapsoro and Fadhilla, 2017).

In this paper, the volatility of stock price, trading volume, and bid-ask spreads are used as indicators to measure economic consequences.

\subsubsection{Bid-Ask Spread}

Bid-ask spread is the difference between the highest purchase price with the lowest selling price (Fabozzi and Modigliani, 1996). Stoll (1989) stated that bid-ask spread is a function of three cost components derived from order processing, the stock owners, and information asymmetry. 
Companies with lower disclosure rates have higher the bid-ask spread, and vice versa (Welker, 1995) and (Sengupta, 1998). The bid-ask spread is used in this proxy since the bid-ask spread can measure information asymmetries (Leuz and Verrecchhia, 2000). The lower information asymmetry implies the lower adverse selection, which further implies the lower bid-ask spread.

According to Hapsoro and Fadhilla (2017), high bid-ask spreads arise due to asymmetric information costs incurred by the company. The expense is incurred because the informed traders and uninformed traders do not have the same information. Information that is not balanced will lead to the occurrence of moral hazard behavior.

\subsubsection{Trading Volume}

Yatini and Maulana (2013) explain that trading activities on the stock exchange can be reflected in the volume of share trading. Stock trading volume can be seen from the number of shares traded on the stock at a certain time.

The trading volume is a measurement of liquidity because trading volume indicates investors' desire to buy and sell shares (Leuz and Verrecchhia, 2000). Widayanto and Sunarjanto (2005), stated that the trading volume that can be seen in the stock market could be an indicator to see the reaction of factors in reacting to a particular event. Share trading volume, as measured by trading volume activity, can see a good or bad market reaction.

Investor's supply and demand for shares will be reflected in trading volume. A high amount of supply and demand for shares will increase trading volume. Furthermore, high trading volume is one indicator that investors are interested in the company's shares (Hapsoro and Fadhilla, 2017).

\subsubsection{Share Price Volatility}

Jain (2001) explains that volatility is the standard deviation used to calculate stock trading's daily price range. Hapsoro and Fadhilla (2017) said that share price volatility is a statistical measurement of fluctuations in stock prices over a certain period. This 
measurement measures the level of variance in a short time, not the price level. Stock price volatility is often perceived as a risk. That is, high stock price volatility is an indicator that the risk of a stock is high. Generally, companies that have low stock price volatility are stable, and vice versa.

According to Hapsoro (2006), insignificant and the tendency of soft stock price changes indicate that there is little data asymmetry between shareholders and companies or between investors and other investors. The low share price volatility indicates less information asymmetry.

Bushee and Noe (2000) suggest that the disclosure effect of volatility is very complex and depends on the type of investor (institution) interested. Broad disclosure of information will reduce information asymmetry between various parties, both management and external parties. Thus, the stock price volatility will be low if the disclosure of information by the company is increasingly widespread.

\subsection{Hypothesis Development}

\subsubsection{The Effect of Eco-Control on Carbon Emission Disclosure}

Eco-control integrates environmental and information costs in environmental management strategies and helps companies control, measure, and disclose company performance (Schaltegger and Burritt, 2000). Eco-control will benefit the company economically with additional information available, form an example related to expenses and benefits of each environmental management strategy that will be carried out (Said et al., 2003). According to Simons (1990), eco-control is a formal system and procedure using ecological and financial information to maintain or change the pattern of company operational activities related to the environment. Eco-control can also assist in developing and improving organizational control capabilities to achieve continuous competitive advantage and the best performance (Henri and Journeault, 2010).

According to Nuwan and Lee (2015), integrating environmental costs and information into an environmental management strategy is one of the benefits offered by eco-control. According to EMA, eco-control was initially introduced to assist 
companies in measuring, controlling, and revealing environmental performance (Henri and Journeault, 2010). Rahmadhani and Meylani (2016) show that eco-control has a positive effect on corporate social responsibility disclosure. The company's deep concern for the environment encourages companies to make environmental management better. The company will be responsible and make efforts for the impacts resulting from its business activities. These impacts include waste and air waste pollution. The carbon emissions disclosure data is one form of corporate responsibility for the environment contained in the company's annual report and financial statements. Hence, the researcher proposed the following hypothesis:

H1: Eco-control has a positive effect on carbon emission disclosure.

\subsubsection{The Effect of Company Age on Carbon Emission Disclosure}

According to Sullivan and Gouldson (2013), industrial activity has a contribution to greenhouse gases in the earth's atmosphere. The company is expected to carry out social and environmental responsibility for carbon emissions that have been donated in the earth's atmosphere. The activity can be informed in the disclosure. It is a form of responsibility to stakeholders.

According to Wartick and Mahon (1994), social values in the community environment always develop over time. Therefore, companies are always required to be able to adjust to the values prevailing in society so that there is no legitimacy gap between the two. Juhmani (2014) stated that companies that are older and have a long relationship with the community would more easily get legitimacy from stakeholders. This shows that the longer or older the company, the more environmentally responsible the company will be. This responsibility can be realized in the form of disclosure.

Research conducted by Ghomi and Leung (2013) found that the company age affects GHG disclosure, while Juhmani (2014) showed that the company age does not affect corporate social responsibility disclosure. According to past research studies, the research will make re-testing of the effect of disclosure on the bid-ask spread. Taking all the above reasons, this research proposed the following hypothesis: 
H2: The company age has a positive effect on carbon emission disclosure.

\subsubsection{The Effect of Company Size on Carbon Emission Disclosure}

The size of the company can represent the number of operational activities. In general, a larger company will likely have more activities (Irwanthoko and Basuki, 2016). The business activities of the company are usually related to the environment directly or indirectly. Therefore, companies must also manage environmental impacts as a side effect of these operational activities to support company performance.

Guthrie et al. (2004) stated that, in stakeholder theory, it is explained that management conducts activities as expected by stakeholders and reports them to stakeholders. As the business world develops, management is implicitly accountable to stakeholders such as governments, creditors, analysts, the public, and the environment, not only to shareholders. The bigger the size of the company shows the greater operational actions carried out by the company. These operational activities have an impact or pollution on the surrounding environment. Therefore, if the company's size is bigger, the greater the company's responsibility to the environment. The company realizes this responsibility in the form of broader disclosure of environmental information to stakeholders.

More significant social pressure in making voluntary disclosures will be obtained by larger companies stuck up to smaller companies (Choi et al., 2013). Company size is directly proportional to the company's detailed information regarding pollution (Freedman and Jaggi, 2005). That is, large companies need to disclose increasingly detailed information. Therefore, companies that produce more carbon emissions from operational activities will provide greater voluntary disclosure.

Previous researchers have done some studies on the effect of company size on carbon emission disclosure. Choi et al. (2013) showed that company size affects the disclosure of carbon emission. Meanwhile, according to Irwanthoko and Basuki (2016), company size does not affect the carbon emission disclosure. 
Based on the above description, there are two different results related to research on the effect of company size on carbon emission disclosure. Therefore, the researcher proposed the following hypothesis:

H3: Company size has a positive effect on carbon emission disclosure.

\subsubsection{The Impact of Carbon Emission Disclosure on Bid-Ask Spread}

Signal theory defines management activities' information should be conveyed to stakeholders in financial statements (Jama'an, 2008). Hartono (2014) said that the information of financial statement does contain financial information and non-financial information. It will give a signal to investors in decision making. Reducing information asymmetry can increase the company's value and reduce uncertainty for the company's prospects. Based on the description above, disclosure of carbon emission is expected to provide economic benefits or economic consequences to investors.

The spread of bid-ask is the difference from the highest demand for share prices and the lowest supply for share prices. A high bid-ask spread between supply and demand prices indicates that the information asymmetry is higher (Hapsoro and Zidni, 2015). Voluntary disclosure or carbon emission disclosure can be used to make internal or external decisions and reduce information asymmetry (Hapsoro, 2006 and Andrew and Cortese, 2011).

The past research studies (Hapsoro and Zidni, 2015; Hapsoro and Fadhilla, 2017) related to the bid-ask spread and voluntary disclosure were different. The researcher will review the impact of voluntary disclosure (carbon emission disclosure) on the bidask spread. Taking all the above reasons, the researcher decided to test this hypothesis:

\section{H4: Carbon emission disclosure has a negative effect on the bid-ask spread}

\subsubsection{The Impact of Carbon Emission Disclosure on Trading Volume}

According to Vijaya (2012), trading volume can be used as an indicator to see the liquid or illiquid of stock in the capital market, which is a description of the company's condition. According to Hapsoro and Zidni (2015), the trading volume reflects supply 
and demand for a stock. The supply and demand volumes increase, the trading will increase. A high volume of trading shows that the stocks are in demand by investors.

The volume of trading is the description of investor interest in selling and purchasing shares (Leuz and Verrecchia, 2000). One of the fundamental evaluation elements that most influence security is information availability (Sun, 2003). The result of the past research studies (Nurdin and Cahyadinto, 2006 and Leuz and Verrecchia, 2000) related to the voluntary disclosure and the trading volume was different. The researcher will review the impact of voluntary disclosure of carbon emission on the trading volume. Taking all the above reasons, the researcher decided to test this hypothesis:

H5: Carbon emission disclosure has a positive impact on trading volume

\subsubsection{The Impact of Carbon Emission Disclosure on Share Price Volatility}

Share price volatility measures the fluctuation of share price or the degree of variance during a one-year. A high share price volatility shows a high data asymmetry. Bushee and Noe (1999) conclude which more information in disclosure will give a good signal to the market and eliminate the uncertainty caused by the information. Good disclosure will decrease price volatility. Cormier et al. (2010) showed that social and environmental disclosure would reduce data asymmetry in the stock market; decreasing information asymmetry is assessed by decreasing share price volatility.

Hapsoro and Zidni (2015) showed that corporate social responsibility does not affect share price volatility, while Cormier et al. (2010) showed that social and environmental disclosure have a negative impact on share price volatility. The result of the past research studies (Cormier et al., 2010; Hapsoro and Zidni, 2015) related to the voluntary disclosure and the share price volatility was different. The researcher will review the impact of voluntary disclosure (carbon emission disclosure) on the share price volatility. Taking all the above reasons, the researcher decided to test this hypothesis.

H6: Carbon emission disclosure has a negative impact on share price volatility 


\subsection{Research Model}

The research model is shown in Figure 1.

Figure 1

Research Model

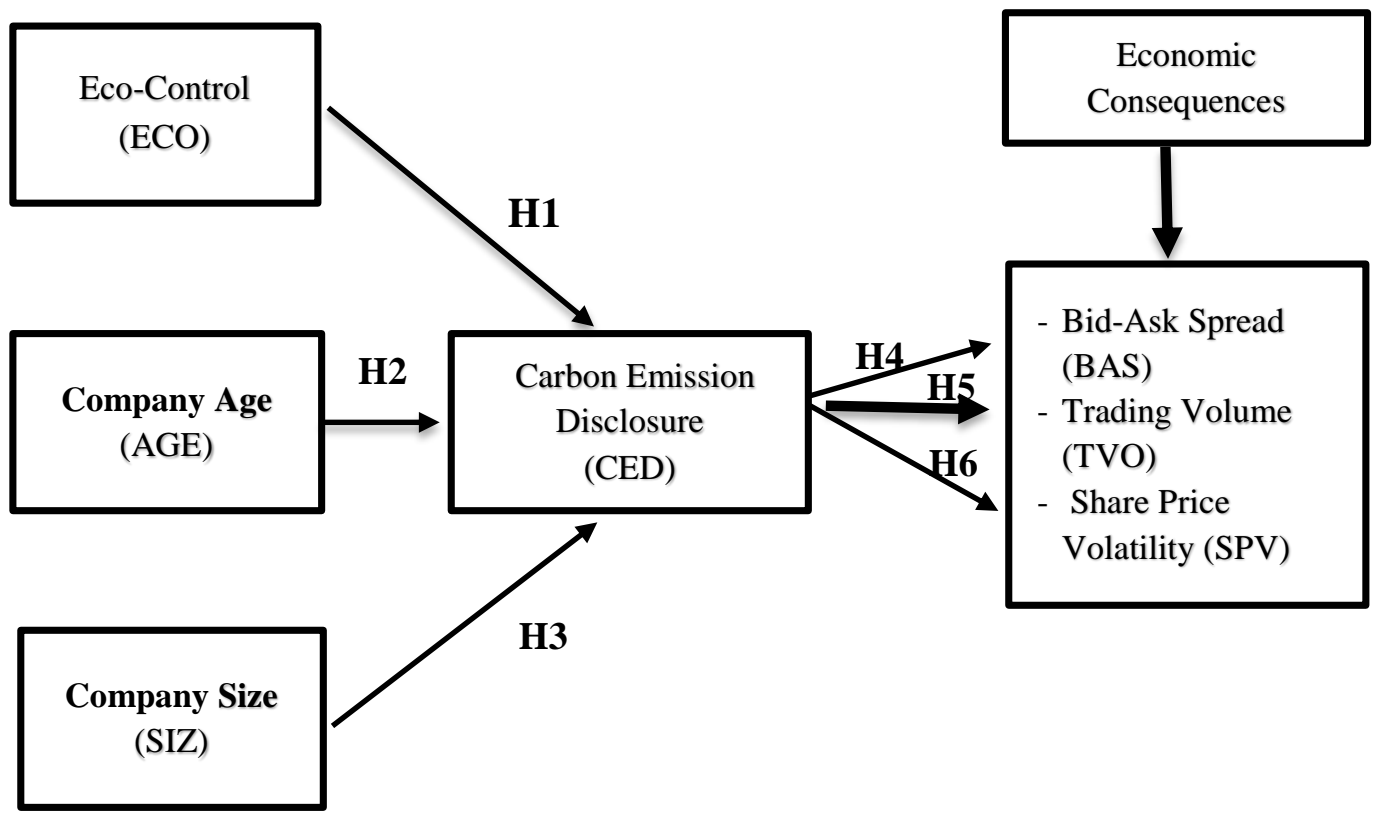

\section{Research Method}

\subsection{Population and Sample}

The companies of gas, coal, and oil of the Non Annex I member countries on the Osiris are the population in this research. The observation is four years (2013-2016). The determination of the four-year observation period from 2013 to 2016 is based on the reason that the second Kyoto Protocols' commitment to reducing carbon emissions began in 2013 and 2016 is the end of the observation period.

The sample is an annual report of the company in English or Bahasa, and the company has a historical stock price from 2013 to 2016 on the website of Yahoo Finance. The sample in this research is 68 companies' data. This study used Structural Equation Modeling (SEM), and the analytical tool used in this method is the software Partial Least Squares (PLS). 


\subsection{The Measurement of Variable Operational}

\subsubsection{Eco-Control}

Eco-control is composed of three important practices: performance measures, budgeting, and incentives (Henri and Journeault, 2010; Rahmadhani and Meylani, 2016). Eco-control variables are measured using three proxies, namely ROA, budgeting, and incentives. ROA is calculated using a dummy variable. If the ROA of a company is greater than the average ROA of all companies, then it will be given a score of 1 , and if ROA of a company is smaller than average ROA of all companies, then it will be given a score of 0 . Furthermore, budgeting and incentives are also measured using dummy variables through content analysis. The company would be given a one if its annual report disclosed the purpose of environmental costs and revenues derived from recycling the remaining material and investments related to environmental care. The company will be given a 0 if the annual report does not disclose the purpose of environmental costs and the income derived from recycling the remaining material and investments related to environmental care. After three proxies have been assessed, the next step is to add up the three proxy scores.

\subsubsection{Company Age}

The company age reveals that the company can contend. The calculation of company age is calculated from the company stance until 2016.

\subsubsection{Company Size}

Company size can be classified by the number of assets, total sales, market capitalized, and others (Machfoedz, 1994). The company size formula in this research is $\mathrm{Ln}$ (total assets).

\subsubsection{Carbon Emission Disclosure}

Carbon emission disclosure is measured by using dummy variables through content analysis. The disclosure of carbon emission is measured by giving a 1 score towards the company that conducts carbon emission disclosure and 0 scores towards the company who did not. The items used to measure carbon emission disclosure are adopted from Choi et al. (2013), as shown in Table 1. 
Table 1

Carbon Emission Disclosure Checklist

\begin{tabular}{|c|c|}
\hline Category & Indicator \\
\hline \multirow{2}{*}{$\begin{array}{l}\text { Climate } \\
\text { change: risks } \\
\text { and } \\
\text { opportunities }\end{array}$} & $\begin{array}{l}\text { CC1. Assessment/description of the risks (regulatory, physical, or } \\
\text { general) relating to climate change and actions are taken or to be } \\
\text { taken to manage the risks. }\end{array}$ \\
\hline & $\begin{array}{l}\text { CC2. Assessment/description of current (and future) financial } \\
\text { implications, business implications and opportunities of climate } \\
\text { change }\end{array}$ \\
\hline \multirow[t]{7}{*}{$\begin{array}{l}\text { GHG emissions } \\
\text { accounting }\end{array}$} & $\begin{array}{l}\text { GHG1. Description of the methodology used to calculate GHG emissions } \\
\text { (e.g., GHG protocol or ISO) }\end{array}$ \\
\hline & $\begin{array}{l}\text { GHG2. Existence of external verification of the quantity of GHG } \\
\text { emission. If so, by whom and on what basis. }\end{array}$ \\
\hline & GHG3. Total GHG emissions. Metric tonnes CO2-e emitted. \\
\hline & GHG4. Disclosure of Scopes 1 and 2, or Scope 3 direct GHG emissions \\
\hline & GHG5. Disclosure of GHG emissions by sources (e.g., coal, electricity) \\
\hline & GHG6. Disclosure of GHG emissions by facility or segment level \\
\hline & GHG7. Comparison of GHG emissions with previous years \\
\hline \multirow{3}{*}{$\begin{array}{l}\text { Energy } \\
\text { consumption } \\
\text { accounting }\end{array}$} & EC1. The total energy consumed (e.g. tera-joules or beta-joules) \\
\hline & Quantification of energy used from renewable sources \\
\hline & Disclosure by type, facility or segment \\
\hline \multirow{4}{*}{$\begin{array}{l}\text { GHG reduction } \\
\text { and cost }\end{array}$} & Detail of plans or strategies to reduce GHG emissions \\
\hline & $\begin{array}{l}\text { Specification of GHG emissions reduction target level and target } \\
\text { year }\end{array}$ \\
\hline & $\begin{array}{l}\text { RC3. Emissions reductions and associated costs or savings achieved to } \\
\text { date as a result of the reduction plan. }\end{array}$ \\
\hline & $\begin{array}{l}\text { RC4. Cost of future emissions factored into capital expenditure } \\
\text { planning. }\end{array}$ \\
\hline \multirow{2}{*}{$\begin{array}{l}\text { Carbon } \\
\text { emission } \\
\text { accountability }\end{array}$} & $\begin{array}{l}\text { ACC1. An indication of which board committee (or other executive } \\
\text { body) has overall responsibility for climate change actions }\end{array}$ \\
\hline & $\begin{array}{l}\text { ACC2. Description of the mechanism by which the board (or other } \\
\text { executive body) reviews the company's progress regarding } \\
\text { climate change }\end{array}$ \\
\hline
\end{tabular}

Source: Choi et al. (2013)

\subsubsection{Bid-Ask Spread}

Bid-ask spread is a difference between supply and demand share price. The bid-ask spread can be calculated by:

$$
\text { Bid-Ask Spread }=\frac{\{(\text { bidi,t-aski, } \mathrm{t}) /(\text { bidi, } \mathrm{t}+\text { aski, } \mathrm{t}) / 2\} \times 100}{n}
$$

Spread $_{\mathrm{i}, \mathrm{t}}=\quad$ The average difference between supply and demand share price of the i firm in a year. 
Ask $=$ The price of demand.

Bid $=$ The price of supply.

$\mathrm{N}=$ The total of transaction days in a year.

\subsubsection{Trading Volume}

The trading volume indicates the selling and buying stocks transactions. The trading volume can be measured by:

$$
T V_{i}=\frac{\sum_{t=1}^{n} T V_{i, t}}{n}
$$

$\mathrm{TVi}=$ The average trading volume of the stock of the $i$ company in one year

$\mathrm{TV} \mathrm{i}, \mathrm{t}=$ The daily trading volume of the $i$ company's stock for one year, the total transaction days for in one year.

$\mathrm{n}=$ The total transaction days in a year.

\subsubsection{Share Price Volatility}

The volatility of the share price the same as the standard deviation of the average daily share price. Share price volatility can be measured by:

$$
\sigma_{i}^{2}=\frac{\sum_{t=1}^{n}\left(X_{i, t}-\bar{X}_{i}\right)^{2}}{n-1}
$$

$\sigma_{i}^{2} \quad=$ variance

$\sigma_{i} \quad=$ Standard deviation

$\overline{\boldsymbol{X}}_{i} \quad=$ The average company's daily share price

$\boldsymbol{X}_{i, t} \quad=$ Each company's daily share prices of one year

$\mathrm{n}=$ Total transaction days in a year. 


\section{Results of Research and Discussion}

\subsection{Descriptive Statistics}

Table 2 showed the descriptive statistics.

Table 2

Descriptive Statistic

\begin{tabular}{lcrrrr}
\hline & N & Minimum & Maximum & Mean & Std. Deviation \\
\hline ECO & 68 & 0.00 & 3.00 & 2.12 & 0.67 \\
\hline CED & 68 & 2.00 & 17.00 & 9.73 & 4.37 \\
\hline BAS & 68 & 0.10 & 2.11 & 0.75 & 0.37 \\
\hline TVO & 68 & 6.44 & 19.28 & 14.26 & 2.88 \\
\hline SPV & 68 & 0.03 & 3.90 & 0.63 & 0.64 \\
\hline SIZ & 68 & 19.57 & 29.11 & 24.02 & 3.16 \\
\hline AGE & 68 & 7.00 & 64.00 & 25.92 & 14.38 \\
\hline Valid N (listwise) & 68 & & & & \\
\hline
\end{tabular}

Source: SPSS output

\subsection{The Partial Least Square Analysis}

Model fit indices are requirements for processing data with WarpPLS. Model fit indices are used to determine the data quality and the suitability of the model with data. Average R-Squared is an assessment of the dependent, endogenous, and exogenous variables. Average R-Squared (ARS) qualifies when the p-value $<0.05$. Average Path Coefficient is an assessment of the relationship between variables. Average Path Coefficient (APC) qualifies when the p-value $<0.05$. Average Variance Inflation Factor is an assessment of multicollinearity. Average Variance Inflation Factor (AVIF) qualifies if the AVIF value 5. The model fit indices of this study can be seen in Table 3. The analysis test result can be seen in Figure 2. The Stone-Geosser Qsquare $\left(\mathrm{Q}^{2}\right)$ useful to determine the goodness of fit model. The value of $\mathrm{Q}^{2}$ in this study is:

$$
\begin{aligned}
\mathrm{Q}^{2} & =1-\left(1-\mathrm{RCED}^{2}\right)\left(1-\mathrm{RBAS}^{2}\right)\left(1-\mathrm{RTVO}^{2}\right)\left(1-\mathrm{RSPV}^{2}\right) \\
& =1-(1-0.28)(1-0.05)(1-0.09)(1-0.08) \\
& =0.43
\end{aligned}
$$


$\mathrm{Q}^{2}$ is 0.43 ; it means that eco-control, company size, company age can describe the carbon emission disclosure, share price volatility, trading volume, and bid-ask spread as much as $43 \%$ and other variables outside this study explain the remaining $57 \%$. Indices of model fit are shown in Table 3.

Table 3

Model Fit Indices

\begin{tabular}{cccc}
\hline Value & P-Value & Criteria & Result \\
\hline APC $=0.262$ & $\mathrm{P}=0.001$ & Good If $\mathrm{P}<0.05$ & Accepted \\
\hline ARS $=0.124$ & $\mathrm{P}=0.041$ & Good If $\mathrm{P}<0.05$ & Accepted \\
\hline AVIF $=1.156$ & & $\mathrm{P}<5$ & Accepted \\
\hline \multicolumn{2}{c}{ Source: Data Processing } &
\end{tabular}

Figure 2

Analysis Results of PLS

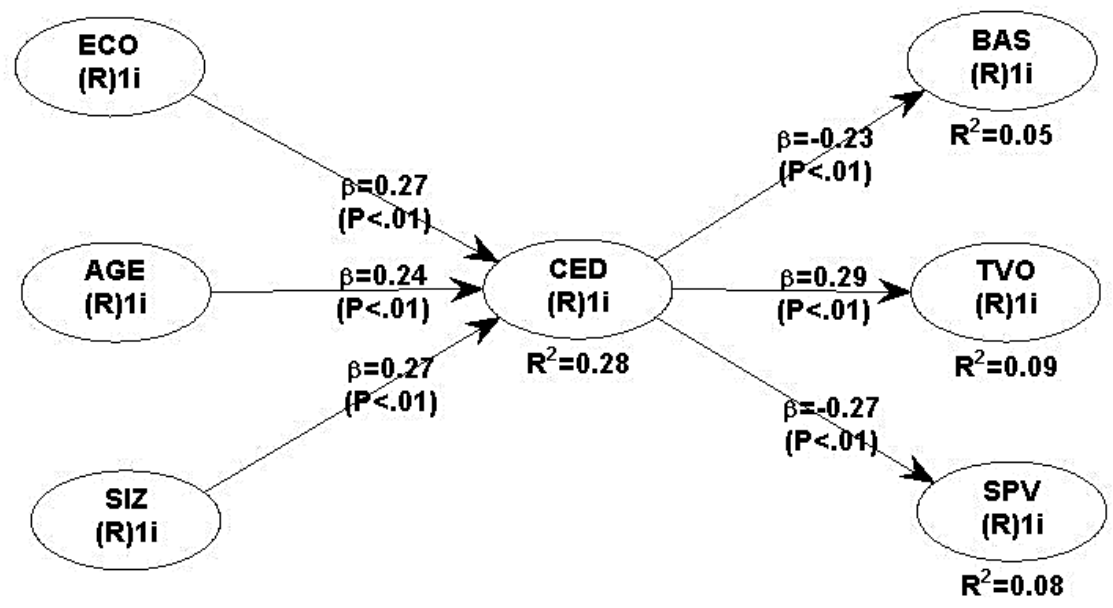

\subsection{Discussion}

\subsubsection{The Impact of Eco-Control on Carbon Emission Disclosure}

The result of the first hypothesis testing shows that the $p$-value $(\leq 0.05)$ and the value of the path coefficient are positive (0.27). The test result indicates that eco-control has a positive impact on carbon emission disclosure. The test result supports the first hypothesis. A firm that has a high level of environmental awareness will have good ecocontrol. A company that has conducted good eco-control will normatively disclose carbon emissions, as a signal or good information for stakeholders. 


\subsubsection{The Impact of Company Age on Carbon Emission Disclosure}

Based on the result of the second hypothesis testing, it shows that the p-value $(<0.01)$ and the value of the path coefficient is positive (0.24). The result indicates that company age has a positive impact on the carbon emission disclosure. The test result supports the second hypothesis. With its old age, the company has much time to build networks with stakeholders from various sectors, such as the research center and other stakeholders who care about various issues, especially environmental management.

\subsubsection{The Impact of Company Size on Carbon Emission Disclosure}

Based on the result of the third hypothesis testing, it shows that the p-value $(<0.01)$ and the value of the path coefficient is positive (0.27). The result indicates that company size has a positive impact on carbon emission disclosure. The test result supports the third hypothesis. A big company will give more information related to pollution (Freedman and Jaggi, 2005). The company that produces more carbon emission from operational activities are expected to provide carbon emission disclosure in the annual report.

\subsubsection{The Impact of Carbon Emission Disclosure on Bid-Ask Spread}

Based on the result of the fourth hypothesis testing, it shows that the p-value $(<0.01)$ and the value of the path coefficient is negative $(-0.23)$. The result indicates that carbon emission disclosure has a negative impact on the bid-ask spread. The test result supports the fourth hypothesis. The more carbon information in the annual report, it will reduce data asymmetry and bid-ask spread.

\subsubsection{The Impact of Carbon Emission Disclosure on Trading Volume}

Based on the result of the fifth hypothesis testing, it shows that the p-value $(<0.01)$ and the value of the path coefficient is positive (0.29). The result indicates that carbon emission disclosure has a positive impact on trading volume. The test result supports the fifth hypothesis. This shows that investors are interested in companies that make 
carbon emission disclosure, so the higher the companies' disclosures, the higher the volume of trading.

\subsubsection{The Impact of Carbon Emission Disclosure on Share Price Volatility}

Based on the result of the sixth hypothesis testing, it is shown that p-value $(<0.01)$ and the value of the path coefficient is negative $(-0.27)$. The result indicates that carbon emission disclosure has a negative impact on share price volatility. The test result supports the sixth hypothesis. The more carbon information in the annual report's disclosure, it will decrease information asymmetry and volatility of share price.

\section{Conclusion, Implication, and Limitation}

\subsection{Conclusion}

This research concludes that eco-control has a positive impact on the disclosure of carbon emission. Companies that have a great concern for the environment will carry out carbon emissions due to operational activities in their annual reports. Disclosure of carbon emission is also one form that the company carries out environmental management well; Firm age has a positive impact on disclosure of carbon emission. With its old age, the company has much time to build networks with stakeholders from various sectors, for example, research center and other stakeholders who care about various issues, especially environmental management; Firm size has a positive impact on disclosure of carbon emission. The company that produces more carbon emissions from operational activities is expected to provide disclosure of carbon emission in the annual report; Disclosure of emission has a negative impact on bid-ask spread and share price volatility. The more carbon information in the annual report, it will reduce data asymmetry and bid-ask spread; Carbon emission disclosure has a positive impact on trading volume. Investors are interested in companies that make carbon emission disclosure, so the higher the disclosures made by companies, the higher the trading volume; Disclosure of emission has a negative impact on share price volatility. The more carbon information in the annual report's disclosure, it will decrease information asymmetry and share price volatility. 


\subsection{Implication and Limitation}

This study has implications for those interested in environmental management, namely the government. At present, regulations related to disclosure of carbon emission are still voluntary. The government is expected to make carbon emission disclosure regulations mandatory so that indirectly more and more companies are increasingly concerned about the government. The research also has implications for companies that produce carbon emission. Based on this study's result, carbon emission should be disclosed in the disclosure of the annual report. Disclosure of carbon emission shows that the company cares about the environment - the disclosure of carbon emission also has a positive effect on the company's financial performance.

This study has limitations for future research. The limitations are that the total sample is small; the sample is only data from gas, coal, and oil companies in the Osiris database for four years (2013-2016). This is due to differences in the language, not completion of the annual report, and information's lack presented in the annual report. The sample in this research only gas, coal, and oil industries. It cannot reflect the reaction of the stock market.

\section{References}

Ahmad, N. N. N., and Hossain, D. M. (2015). Climate Change and Global Warming Discourses and Disclosures in the Corporate Annual Reports: A Study on the Malaysian Companies. Procedia-Social and Behavioral Sciences, 172: 246-253.

Andrew, J., and Cortese, C. L. (2011). Carbon Disclosures: Comparability, the Carbon Disclosure Project, and the Greenhouse Gas Protocol. Australian Accounting Business and Finance Journal, 5(4): 5-18.

Barako, D. G., Hancock, P., and Izan, H. Y. (2006). Factors Influencing Voluntary Corporate Disclosure by Kenyan Companies. Journal Compilation Oxford, 14(2): 107-125.

Bebbington, J., and C. L. Gonzales. 2008. Carbon Trading: Accounting and Reporting Issues. European Accounting Review 17 (4):697-717.

Bennett, M., Bouma, J. J., and Wolters, T. (2002). Environmental Management Accounting: Informational and Institutional Developments. Dordrecht, Netherlands: Kluwer Academic Publisher. 
Berthelot, S., and Robert, A. M. (2011). Climate Change Disclosures: An Examination of Canadian Oil and Gas Firms. Issues in Social and Environmental Accounting, 5(1): 106123.

Bushee, B. J., and Noe, C. F. (2000). Corporate Disclosure Practices, Institutional Investors, and Stock Return Volatility. Journal of Accounting Research, 38: 171-202.

Choi, B. B., Lee, D., and Psaros, J. (2013). An Analysis of Australian Company Carbon Emission Disclosures. Pacific Accounting Review, 25(1), 58-79.

Comyns, B., and Figge, F. (2015). Greenhouse Gas Reporting Quality in the Oil and Gas Industry: A Longitudinal Study Using the Typology of "Search", "Experience" and "Credence" Information. Accounting, Auditing \& Accountability Journal, 28(3): 403433.

Cormier, D., Ledoux, M. J., and Magnan, M. (2010). The Informational Contribution of Social and Environmental Disclosures for Investors. Retrieved October 3, 2017, from https://hal.archives-ouvertes.fr/hal-00481571.

Fabozzi, F. J. and Modigliani, F. (1996). Capital Markets. 2nd Edition. London: Prentice-Hall International, Inc.

Freedman, M., and B. Jaggi. (2005). Global Warming, Commitment to The Kyoto Protocol, and Accounting Disclosures by The Largest Global Public Firms From Polluting Industries. The International Journal of Accounting, 40(3): 215-232.

Ghomi, Z. B. and P. Leung. (2013). An Empirical Analysis of the Determinants of Greenhouse Gas Voluntary Disclosure in Australia. Accounting and Finance Research, 2(1): 110127.

Gozali, N. O., How, J. C. Y. and Verhoeven, P. (2002). The Economic Consequences of Voluntary Environmental Information Disclosure. The International Environmental Modelling and Software Society, 2: 484-489.

Gray, R., Kouhy, R., and Lavers, S. (1995). Constructing a Research Database of Social and Environmental Reporting by UK Companies. Accounting, Auditing \& Accountability Journal, 8(2): 78-101.

Gray, Rob, Jan Bebbington, and Sue Gray). (2010). Social and Environmental Accounting. Los Angeles, CA: SAGE: Library in Accounting and Finances.

Guthrie, J., Petty, R., Yongvanich, K., and Ricceri, F. (2004). Using Content Analysis as a Research Method to Inquire into Intellectual Capital Reporting. Journal of Intellectual Capital, 5(2): 282-293. 
Hapsoro, Dody (2006). Mekanisme Corporate Governance, Transparansi dan Konsekuensi Ekonomik: Studi Empiris di Pasar Modal Indonesia. Unpublished Ph.D. Thesis, Universitas Gadjah Mada, Yogyakarta, Indonesia.

Hapsoro, Dody, and Zidni, Muhammad Harits. (2015). The Effect of Corporate Social Responsibility Disclosure on Economic Consequences: Case Study in Indonesia. Journal of Business and Economics, 6(9): 1595-1605.

Hapsoro, Dody, and Fadhilla, A. F. (2017). Relationship Analysis of Corporate Governance, Corporate Social Responsibility Disclosure, and Economic Consequences: Empirical Study of Indonesia Capital Market. The Southeast Asian Journal of Management, 11(2): 164-182.

Hartono, Jogiyanto. (2014). Teori Portofolio dan Analisis Investasi. 9th Edition. Yogyakarta: BPFE UGM.

Healy, M. P, and Palepu, K. G. (2001). Information Asymmetry, Corporate Disclosure, and the Capital Markets: A Review of the Empirical Disclosure Literature. Journal of Accounting and Economics, 31: 405-440.

Henri, J. F., and Journeault, M. (2010). Eco-Control: The Influence of Management Control Systems on Environmental and Economic Performance. Accounting, Organizations, and Society, 35: 63-80.

Henri, J. F., Journeault, M, and Brousseau, C. (2017). Eco-Control Change and Environmental Performance: A Longitudinal Perspective. Journal of Accounting \& Organizational Change, 13(2): 188-215.

Hermawan, Atang, Isye Siti Aisyah, Ardi Gunardi, Wiratri Yustia Putri. (2018). Going Green: Determinants of Carbon Emission Disclosure in Manufacturing Companies in Indonesia. International Journal of Energy Economics and Policy, 8(1): 55-61.

Irwanthoko and Basuki. (2016). Carbon Emission Disclosure: Studi pada Perusahaan Manufaktur Indonesia. Jurnal Akuntansi dan Keuangan, 18(2): 92-104.

Ittner, C. D., Larcker, D. F., and Randall, T. (2003). Performance Implications of Strategic Performance Measurement in Financial Services Firms. Accounting, Organizations, and Society, 28(7-8): 715-741.

Jain, R. K. (2001). Putting Volatility to Work. Retrieved August 9, 2017, from www.activetradersmag.com.

Jama'an. (2008). Pengaruh Mekanisme Corporate Governance dan Kualitas Kantor Akuntan Publik terhadap Integritas Informasi Laporan Keuangan. Unpublished Master Thesis, Universitas Diponegoro, Semarang. 
Juhmani, O. (2014). Determinants of Corporate Social and Environmental Disclosure on Websites: The Case of Bahrain. Universal Journal of Accounting and Finance, 2(4): 77-87.

Lash, J, and Wellington, F. (2007). Competitive Advantage on a Warming Planet. Harvard Business Review, 1-11.

Lawer, C., and Andreas. 2013. Pengaruh Karakteristik Perusahaan terhadap Pengungkapan Tanggungjawab Sosial. Jurnal Ekonomi, 19(02): 1-10.

Leuz, Christian, and Robert E. Verrecchia. (2000). The Economic Consequences of Increased Disclosure. Journal of Accounting Research, 38: 91-124.

Leuz, C., and Wysocki, P. D. (2016). The Economics of Disclosure and Financial Reporting Regulation: Evidence and Suggestions for Future Research. Journal of Accounting Research, 54(2): 525-622.

Machfoedz, Mas'ud. (1994). Financial Ratio Characteristic Analysis and The Prediction of Earnings Changes in Indonesia. Kelola, 7: 114-133.

Merchant, K. A. (1982). The Control Function of Management. Sloan Management Review, 23(4): 43-55.

Najah, Muftah Mohamed Salem. (2012). Carbon Risk Management, Carbon Disclosure, and Stock Market Effects: An International Perspective. Unpublished Dissertation, University of Southern Queensland, Australia.

Nurdin, E. and Cahyandito, M. F. (2006). Pengaruh Kualitas Pengungkapan Sosial dan Lingkungan dalam Laporan Tahunan terhadap Reaksi Investor. Unpublished Master Thesis, Universitas Padjajaran, Bandung, Indonesia.

Nuwan, Gunarathne, and Lee, Ki-Hoon. (2015). Environmental Management Accounting (EMA) for Environmental Management and Organizational Change: An Eco-Control Approach. Journal of Accounting \& Organizational Change, 11(3): 362-383.

Pellegrino, C., and Lodhia, S. (2012). Climate Change Accounting and the Australian Mining Industry: Exploring the Links between Corporate Disclosure and the Generation of Legitimacy. Journal of Cleaner Production, 36: 68-82.

Porter, M. E., and Linde, V. D. (1995). Green and Competitive: Ending the Stalemate. Harvard Business Review, September-October, 120-134.

Rahmadhani, S. and Meylani, D. (2016). Pengaruh Eco-Control terhadap CSR Disclosure dan Financial Performance dengan Environmental Performance sebagai Variabel Intervening. Jurnal Dinamika Ekonomi \& Bisnis, 13(1): 32-46. 
Rahmana, Noor Raida Abd, Siti Zaleha Abdul Rasid, Rohaida Basiruddin. (2014). Exploring the Relationship Between Carbon Performance, Carbon Reporting, and Firm Performance. Procedia-Social and Behavioral Sciences, 164: 118 - 125

Said, A. A., Elnaby, H. R. H., and Wier, B. (2003). An Empirical Investigation of the Performance Consequences of Non-Financial Measures. Journal of Management Accounting Research, 23: 193-223.

Schaltegger, S., and Burritt, R. (2000). Contemporary Environmental Accounting. Greenleaf Publishing, 9: 81-82.

Sengupta, P. (1998). Corporate Disclosure Quality and the Cost of Debt. The Accounting Review, 73(4): 459-474.

Shrivastava, P. (1995). The Role of Corporations in Achieving Ecological Sustainability. Academy of Management Review, 20(4): 936-960.

Simons, R. (1990). The Role of Management Control Systems in Creating Competitive Advantage: New Perspectives. Accounting, Organizations, and Society, 15(1/2): 127143.

Stoll, H. R. (1989). Inferring the Component of the Bid-Ask Spread: Theory and Empirical Test. The Journal of Finance, 44(1): 115-134.

Sullivan, R., and Gouldson, A. (2013). Ten Years of Corporate Action on Climate Change: What Do We Have to Show for It? Energy Policy, 60: 733-740.

Sun, W. (2003). Relationship between Trading Volume and Security Prices and Returns. Area Exam Report MIT Laboratory for Information and Decision Systems, Technical Report, 2638.

Tang, Q. and Luo, L. (2014). Does Voluntary Carbon Disclosure Reflect Underlying Carbon Performance? Journal of Contemporary Accounting \& Economics, 10: 191-205.

Tauringana, V., and Chithambo, L. (2014). The Effect of DEFRA Guidance on Greenhouse Gas Disclosure. The British Accounting Review, 47(4): 425-444.

United Nations Framework Convention on Climate Change (UNFCCC). Retrieved August 10, 2017, from http://unfccc.int/kyoto_protocol/items/2830.php.

Wartick, Steven L, and John F. Mahon. (1994). Toward a Substantive Definition of the Corporate Issue Construct: A Review and Synthesis. Journal of Business \& Society, 33(3): 293 311

Welker, M. (1995). Disclosure Policy, Information Asymmetry, and Liquidity in Equity Markets. Contemporary Accounting Research, 11(2): 801-827. 
Widayanto, Wiwit and Sunarjanto. (2005). Analisis Pengaruh Pengumuman Pemecahan Saham (Stock Split) terhadap Harga Saham, Volume Perdagangan Saham dan Likuiditas Saham yang Diukur dengan Bid-ask Spread pada Beberapa Perusahaan Go Public di Bursa Efek Jakarta. Fokus Manajerial, 3(2): 154-164.

Yatini and Maulana, R. (2013). Analisis Pergerakan Return Saham dan Volume Perdagangan Saham Sebelum dan Sesudah Pengumuman Laporan Keuangan (Penelitian pada Perusahaan Property dan Real Estate di Bursa Efek Indonesia Periode Tahun 20102011). JMA, 18(2): 88-103.

Zeff, S.A. (1978). The Rise of Economic Consequences. The Journal of Accountancy, 46(6): 5663. 